\title{
Women and the Transnational Dynamics of Science Education in Early Twentieth Century China: A Quiet Revolution ${ }^{1}$
}

\section{Grace Yen Shen 沈德容 ${ }^{2}$}

(Fordham University, Bronx, NY 10458, US)

\begin{abstract}
This article explores both the personal and transnational dimensions of domestic science education and study abroad for the pioneering generation of Chinese women in science. By focusing on women's unique calculus of risk and reward, the article not only distinguishes Chinese women's experiences from those of their male counterparts but also delineates the special contours of the Chinese case within the global advancement of women in science. The article begins by outlining some of the features and dynamics of early Chinese girls' schools that affected students' interest in and preparation for further scientific study. Then it traces the emerging college-level opportunities that made it possible for women who were studying science in China to contemplate advanced work overseas. Turning to study abroad, the article highlights the radicalness of the decision to study abroad by examining the impact of both family background and national circumstances on Chinese women's strategies of mobility. The article argues that if we are to take women's experiences seriously, we cannot just look at scientific pursuits in terms of achievements in the development of Chinese science, we also need to consider the ways that scientific ambitions forced individuals-both male and female - to navigate and reimagine multiple social norms and expectations.
\end{abstract}

Keywords: women in science, history of study abroad, Ginling College, early women's science education, transnational history of science

\section{摘 要: 本文从人物与跨国维度探索中国科学界的女性先驱接受的早期科学教育与她们 的留学经历。论文通过重点关注清末民初女性在追求科学的过程中面对的特殊风险与收 获，将当时中国男性与女性在科学道路上的经历区分开来，并揭示出中国女性的案例在 世界女性科学发展史中的特点。本文分为两大部分, 分别探讨国内女子科学教育与女性 出国学习科学的环境和条件。第一部分首先陈述早期创立的女子学校的主要性质与动态}

1 This paper was copyedited by Charlie Zaharoff.

2 Grace Yen Shen's research interests center on questions of identity and aspirations of modernity, change, and self-fulfillment in China during the late nineteenth to the late twentieth century. Email: gshen1@fordham.edu 


\begin{abstract}
机制, 分析它们怎样影响学生对科学产生兴趣, 并帮助她们做好深造的准备, 然后再追 踪新出现的攻读大学学位的机会, 这些机会使得在中国学习科学的女性有可能考虑到海 外深造。第二部分转而关注留学问题, 探讨家庭背景和国际形势何以改造中国女子的 “调 动策略” (strategies of mobility), 强调选择出国进修是激进的人生选择。文章提出, 认 真对待早期从事科学之女子的个人处境, 令我们不再仅将她们的科学追求当作中国科学 发展进程的一部分, 而是关注科学志愿如何推动男女人士周旋于数国的社会规范与要求 之间, 并重塑这些规范。
\end{abstract}

关键词: 女科学家, 留学史, 金陵女子大学, 早期女子科学教育, 跨国科学史

\title{
1 Introduction
}

$\mathrm{I}^{\mathrm{n}}$ recent years, historians have benefited from the growing attention paid to modern China's pioneering female scientists. Appearing in women's interest articles, children's literature, and popular celebrations of gender equality in New China, they are depicted as trailblazing representatives of womanhood whose stories are both affirmations of social progress and models of patriotic achievement for young women to follow. For more specialized scientific and historical readers, educational and departmental histories have taken special note of female scientists as a point of pride for local institutional cultures and as a testament to progressive policies that fostered women's participation in generally male-dominated fields. Similarly, as historical compendia of international women in science have become more common, Chinese women have been consistently well represented.

In addition to showcasing women's scientific activities in modern China, these diverse sources have also helped to merge the stories of individual scientists into a collective narrative of scientific milestones and social progress both for women and for China at large. In the case of China's most accomplished female scientists, such as Wu Jianxiong 吴健雄 and He Zehui 何泽慧, festschrifts and stand-alone biographies have given us a great deal more insight into their roles as researchers, mentors, and public figures. These accounts naturally include a gendered story (for instance, Wu's controversial omission in the 1957 Nobel Prize for parity non-conservation), but in their tendency to cast their subjects as exceptional, they mirror traditional "great man" histories and do not always connect the dots between these scientists, their relation to other women, and the specific realities of early twentieth-century science.

While it is of obvious value to reinsert women into the history of science and to reassert the scientific merit of their contributions, we must try to avoid flattening their experiences into a generic pattern of scientific development modeled on either their male counterparts or their sisters abroad. Each achievement in the chronicle (nianpu 年谱) of a Chinese woman scientist is a window onto a fleeting horizon of possibility that forces us to ponder what scientific attainments might have meant to those who could not take them for granted. Unlike the men who took up science in the late Qing and early 
Republican periods, Chinese women had little reason to assume that their efforts would be rewarded with positions in academia, industry, or politics. The expectation that a woman's life would center on the home vexed advocates of women's rights well into the 1940s, and even feminists who insisted on women's economic independence were often ambivalent about careers that put men and women together in the workplace (Goodman 2005).

In order to understand the dynamics of scientific development in China and the personal significance of science for early Chinese practitioners (Shen 2007), we must pay attention to how women's calculus of risk and reward differed from that of men. For some Chinese women who pursued the sciences through the first decades of the Republican era, their dedication was a leap of faith in both their own abilities and their homeland's potential for social change. For others, the uncertainty of a future in science was more desirable than the certainty of marriage and the narrow confines of the traditional household.

With this in mind, the paper that follows will mainly explore the period from the last years of the Qing dynasty, when the first Chinese women went abroad to study science under state sponsorship, to the mid-1920s, when women's pursuit of science became more routinized in China and advanced study abroad became correspondingly more accessible to a wider range of women. It will discuss both those whose scientific training led to careers in allied fields and those who later became practicing scientists as scientists-in-training during their student years. This allows us to recognize how uncharted science was as a profession in China until the rise of academic departments and disciplinary associations in the 1920s. It also shows that in the early twentieth century, science education and science promotion were as central to the project of establishing modern scientific practice in China as laboratory or field research. However, the paper will not engage extensively with women on an explicitly medical track, not only because medicine had a very different place within the dominant discourses of care and motherhood, but because it benefited from local precedents for female participation, ${ }^{3}$ whereas here I am particularly concerned with the challenges

3 The first Chinese women to study abroad were in fact those studying medicine, such as Jin Yunmei 金韻梅 (Yamei Kin, Y. May King) and Kang Aide 康愛德 (Ida Kahn, born Kang Cheng 康成), whose trajectories were directly shaped by their adoptive American missionary parents and whose materials and experiences have been ably discussed elsewhere. See, for example, Shemo 2011, and Shurtleff and Aoyagi 2016. The idea of women as care-givers fit into the broader “virtuous wives, good mothers" (xianqi liangmu 贤妻良母) discourse and was widely accepted in China at the turn of the twentieth century. As Yamei Kin put it when discussing her chosen vocation, "[t]he dominant note in a woman's life is service" (cited in Ye 2002, 126), and indeed, the Chinese government's choice of medicine as one of the critical specialties that state-sponsored women could study abroad was grounded in the understanding that medicine was a way for women to fulfill their duties to their families and homeland (Chen Y., Chen X., and Tian 2007, 764). For more on the early impact that female doctors of traditional medicine had on developments in women's practice of modern Western medicine, see Shemo 2018. 
and choices involved in women self-consciously blazing trails into scientific study.

The goal of the paper is to explore not only how the transnational dimensions of domestic science education and study abroad distinguished Chinese women's experiences from those of their male compatriots, but also how these transnational factors distinguished the dynamics of the Chinese case from those encountered by women from other backgrounds. To this end, we will begin by considering the difficulties that women in late Qing and early Republican China faced in acquiring the basic science education needed to contemplate more advanced work as well as the development of college-level science training for women in the 1910s, which multiplied options for domestic study and post-graduate experience abroad. Turning our attention to the prospects and demands of overseas study, we will first look at what kinds of women went abroad by considering their family backgrounds and then analyze the strategies of mobility these women employed in pursuit of their scientific ambitions. This will allow us to see how many of the patterns and exigencies that characterized China's early women scientists worked to their advantage while overseas. By locating these women in a transnational web of meaning, I hope to understand more about their personal objectives as well as about the dynamics of Chinese science in a global context.

\section{Scientific training for women}

For Chinese women in earlier periods, such as Qing dynasty astronomer and mathematician Wang Zhenyi 王貞儀, there were opportunities for an interest in natural knowledge to be aroused and cultivated within the home. Though the education of women was not broadly supported, it was not uncommon in more open-minded circles of the literati for women to be exposed to mathematics and nature study by their fathers, brothers, or husbands (in Wang's case, also her grandfather) and pursue a private education. Even where women became highly accomplished and surpassed the men of their family in these interests, there was little sense of competition when men had their sights set on officialdom and the civil service examination system. Similarly, there was no worry about job insecurity or discrimination when the knowledge these women produced would only be circulated within polite social circles, and men often assisted women in their family in publishing their findings, as was the case for another Qing dynasty astronomer, Jiang Hui 江夢, whose work was disseminated posthumously by her doting husband. ${ }^{4}$

4 See Shen 2011 for biographical discussions of over forty such Qing dynasty women "scientists," and Dong 2018 for further statistical analysis. For earlier women with accomplishments in natural knowledge and mathematics, see Lee and Wiles 2015, and Lee and Stefanowska 2015. 
The situation was quite different, however, for young Chinese men who were interested in mastering natural knowledge from the West, whether understood as Western learning (xixue 西學), gezhi 格致, or, later, simply science (kexue 科學). Generally, even progressive and supportive family elders were unfamiliar with the kind of disciplinary learning that was increasingly in demand to strengthen and save the nation. Young men therefore pursued the sciences in arsenals and then modern-style schools, often with hopes of furthering their education abroad in Japan, Europe, or the United States.

Though they were rarely sure of their career prospects, men interested in the modern sciences did not see themselves as the amateur specialists of previous generations and actively sought to apply their training in positions outside of the home. For women, many of whom were also influenced by patriotic calls to modern learning, the sciences thus amplified the barriers to participation by making the spaces of education and practice public and by linking serious study to nation and career. Pursuit of modern science required the upheaval of social norms as well as access to training, and therefore placed different demands on young men and women, their families, and their social roles.

While the development of modern education for women has become increasingly well studied (Wang X. 2015; Xiong 2006), the literature still struggles to balance the progressiveness of early efforts against the gender-specific considerations and constraints built into women's education, especially for those with a budding interest in modern science. In the sections that follow, I will outline some of the features and dynamics of girls' schools that affected students' interest in and preparation for further scientific study, and then trace the emerging college-level opportunities that made it possible for women to study science in China, especially within a missionary context.

\subsection{Early elementary and middle schools}

In the wake of China's shocking defeat in the Sino-Japanese War (1894-1895), several of the most prominent Chinese reformers of the day established a school for girls in Shanghai in 1898 as a model for what they hoped would be the rapid expansion of women's education. ${ }^{5}$ Given that, as late as 1904, the Qing court still could not justify allowing girls to attend school en masse for fear of their "wander[ing] about the streets” (遊行街市) and “improperly learning foreign customs” (誤學外國習俗), the

5 Among the active organizers of the school were Jing Yuanshan 經元善 (chief of the Shanghai Telegraph Bureau), Liang Qichao 梁啟超, Zheng Guanying 鄭觀應, Chen Jitong 陳季同, and Kang Guangren 康廣仁, and the list of over 150 donors and supporters of the school included such figures as Kang Youwei 康有為, Tan Sitong 譚嗣同, Zhang Jian 張謇, Yan Fu 嚴復, and Huang Zunxian 黄遵憲. 
radicalness of such a project was a calculated provocation (Wu 2010,60). ${ }^{6}$ Though this project, the Chinese Girls' School 中國女學堂, also known as Jingzheng Girls' School 經正女塾, was short-lived (1898-1900), their efforts struck a chord with local activists and officials, and by 1907, when the Qing court finally sanctioned women's education, there were over four hundred girls' schools with almost sixteen thousand students in sixteen provinces (Wu 2010, 60; Liu 2009, 105). ${ }^{7}$ Unlike in Meiji Japan, where the Ministry of Education aimed to centralize reform of both private and public women's education, the extra-governmental efforts of both Chinese elites and foreign missionaries brought several different forces to bear on girls' schools in the twilight years of the Qing dynasty, many of which can be seen in the organization of the first Chinese Girls' School.

For Jing Yuanshan 經元善 and other Chinese founders of the school, the inspiration for the school can clearly be traced to Liang Qichao's "On Women's Education" (Lun nüxue 論女學, 1897), which claims that "the root causes of national weakness . . . lie in women's lack of education" (Liang [1897] 2013, 190). Liang based his claim on two arguments that would dominate the discourse of women's rights well into the Republican era. The first was that the strength of the nation rested on the capacity, vigor, and morality of its future citizens, and its future citizens required educated mothers to reach their full potential, or as Liang put it, "the education of men necessarily begins with that of women" (Liang [1897] 2013, 195). The other was that without education, women could not support themselves and would continue to be parasites upon China's men by burdening the productive half of the population with two hundred million consumers that contributed nothing in economic terms. Liang did not elaborate on whether productivity and motherhood were mutually exclusive, or whether he saw enlightened and effective motherhood as inherently sufficient for a woman to earn her keep, but Liang's arguments exhibit a persistent tension between educating women to cultivate themselves and educating women to cultivate others.

From the beginning, the organizers of the Chinese Girls' School sought to involve both Westerners and women for the good of the project, and this also shaped the philosophy of the school. To Liang's maternal and economic arguments, several of the missionaries who supported the school added a civilizational dimension. For instance, Young J. Allen 林樂知 (Lin Lezhi), the American Methodist who had previously helped found Shanghai's McTyeire Girls' School 中西女中 in 1892, believed that "the

6 In actual fact, while it might not have been sufficient reason to withhold official support for girls' education, the "female student" was an entirely new social category that attracted a considerable amount of attention and debate for several decades. For an example of the image of the female student in the periodical press that demonstrates the novelty of female compared to male student in modern schools, see Chen 2008.

7 Neither source distinguishes missionary schools from local gentry schools. 
status of women and their treatment in every country" (各國女人之地位, 與其看待女人 之法) was "the measure for comparing the merits and drawbacks of [each country's] civilization” (為比較教化優劣之定格) (Lin [Allen] 1903, 13b). ${ }^{8}$ Thus, girls' schools in China were not just about wealth and power, but enlightenment and progress. On the other hand, the educated and accomplished literati women involved with the founding of the Chinese Girls' School argued that women's failure to contribute to society stemmed from society's unwillingness to give them opportunities. For women such as Xue Shaohui 薛紹徽, who had been trained in the cainü (才女, literally “talented girl”) mold within her elite household, the value of a girls' school lay in cultivating the abilities of women for public service and "preparing them to be selected for the use of the state" (以备国家有用之选) (quoted in Qian 2003, 424).

Similarly varied perspectives were typical in broader discussions on women's education in schools and in the media. Though the more radical perspectives of literati women were soon subsumed under the umbrella of motherhood and modern domesticity, the idea of virtuous wives and good mothers proved to be quite elastic and included a sometimes surprising range of practices and designs well into the $1930 \mathrm{~s}^{9}{ }^{9}$ In terms of scientific knowledge, activists such as Xue Shaohui were obviously interested in framing a specialty in Western medicine as a form of womanly care-giving, but even the Qing court, which couched its support for women's education in terms of defending traditional values 禮教, stretched its concept of worthy motherhood to include teaching and thus prescribed mathematics and science for women's normal school curricula (Bailey 2007, 30).

Most reformers interested in women's education also felt that knowledge of the sciences would prevent women from holding China back with superstition and ignorance. Though a missionary like Timothy Richard imagined superstition somewhat differently than his Chinese counterparts, he also urged women's schools to "take advantage of Chinese people's new interests in science, mathematics and Western languages by offering such subjects under Christian auspices" (Liu 2009, 97). ${ }^{10}$ This

8 Allen's quotation is from 1903, but it reflects a consistent position espoused in his writing in The Globe Magazine (Wanguo gongbao 萬國公報) over many years.

9 Just how elastic this slogan was in supporting technical knowledge for women is illustrated by the fact that instruction on bomb-making was given to girls at Cai Yuanpei's 蔡元培 Patriotic Girls' School 愛國女學校 under the rationale that mothering the nation included revolutionary activities (Gao 1996, 396-397).

10 While Liang Qichao was concerned about Chinese "superstitions" as an embarrassing obstacle to rational modern thinking, many Protestant missionaries in China saw local "superstitions" as barriers to the acceptance of Christianity, and science was therefore a way of clearing the path to true faith. It is interesting to compare this to the situation in late nineteenth-century France, in which French elites saw Catholicism as an impediment to Republicanism and hoped that teaching women science in the context of homemaking would advance the social and political goal of producing a modern citizenry. See Edwards 1997, ix, 5-7, 21. 
was in line with a notable turn in missionary girls' schools from primarily charitable institutions to institutions that sought to attract China's well-to-do and well-connected literati and merchant classes by raising standards, charging tuition to guarantee prestige, and vouchsafing moral development for girls who boarded far from home (Liu 2009, 96-97).

Given the premium placed upon the promotion of modern science from the last decades of the Qing through the Republican period, it is perhaps unsurprising that most Chinese and missionary schools for women would include science and mathematics in their curricula, but the quality and aims of these courses varied a great deal and reflected the difficulties of providing girls with access to scientific training. Describing conditions around 1907, Margaret Burton noted that all of the missionary schools for women in south China that she observed taught courses in science, though there was little consistency in subject matter: schools chose to emphasize physics, zoology, geology, chemistry, or biology as they wished (Burton 1911, 74). Around the same time, Burton counted twelve girls' schools run by the Chinese gentry in Shanghai and indicated that on top of the basic curriculum, each offered a progressive program, including teachers' preparation, industrial training, and in one case a medical course (Burton 1911, 113). Burton also reported that contrary to expectations based on the situation in Shanghai, urban schools were not necessarily better at teaching the sciences than village schools. Apparently, in the government-sponsored schools in Tianjin that she observed, not all subjects in the official curriculum were actively taught, and physical or chemical apparatus often sat unused on shelves. In contrast, a gentry school that she visited in the rural area outside the city was a vibrant center of education, with science as a real part of the instruction (Burton 1911, 136, 127).

In some cases, the problem of active scientific instruction stemmed from the lack of enthusiasm or funding in government schools compared to the gentry's passion projects. ${ }^{11}$ More often, the difficulty of hiring qualified teachers for special subjects such as science or music was a bigger factor (Burton 1911, 139), and this was a major reason for the official expansion of women's normal schools, some of which began developing special programs in natural science and the arts by 1918 (Cong 2011, 93). Reporting less than a decade after the Republican revolution, American educator Ida Lewis found that in women's "higher schools, algebra, geometry, and mathematics largely replace arithmetic" and the "sciences of biology, botany, chemistry, and physics

11 There might also have been important differences in tuition and funding, but not all gentry schools charged tuition. Alternately, gentry schools might have catered to a different class of girls because of either facilities or social networks. In either case, it is clear that through newspapers and private communications, schools with strong reputations for the quality of their instruction, the strength of their faculty, or specific value-orientations could attract well-to-do students from considerable distances, a fact which, read against the grain, suggests how much standards varied across institutions. On long-distance interest in girls' schools, see, for example, Wang Y. 2015, 172. 
replace geography" (Lewis 1919, 76). While data on the specific content of coursework in Chinese girls' schools is scant and the structure of women's primary and secondary education was in flux for several decades, Lewis' findings suggest that girls' higher middle schools in China aimed for an international standard, since American students applying to college in the United States around the turn of the twentieth century were advised to have two units of mathematics and one of science (Latimer 1958, 68). It also seems clear from Lewis' data that primary and early middle schools that taught physics, botany, or other sciences seemed to be in the minority, but wherever these subjects were in fact present, they took up a significant number (usually three to five) of instructional hours each week, which reinforces the impression of certain institutions placing a particular emphasis on scientific subjects (Lewis 1919, 71-76).

The status of science in girls' schools in the late Qing and early Republican China was not only shaped by domestic initiatives, material resources, and the shifting political situation, it was also affected by several different transnational factors. Despite the friction caused by the Sino-Japanese War, Chinese educators felt that the Meiji state's impressive program of modernization was relevant to China's situation, and Japan's physical accessibility to China made it a ready source for both translated textbooks and teachers in the early years of women's education. This helped reinforce the Japanese idea of ryōsai kenbo 良妻賢母, or "good wives, wise mothers," as the ideal of modern female citizenship, and textbooks for girls insisted that "at present, of the most important branches of learning, the sciences are the most vital" (目今所最重要之 學科, 亦惟理科為最) ( $\mathrm{Wu}$ and $\mathrm{Li} 2014,105) .{ }^{12}$ At the same time, the employment of Japanese instructors at gentry and government girls' schools seemed to undercut science training because many of them could not teach Chinese students without translators (Burton 1911, 140). ${ }^{13}$

In other girls' schools, both missionary and gentry, the ideas of science and motherhood that were imparted grew out of the American Protestant experience. Science instruction was generally given to girls in later years of schooling, when girls were familiar with English and could work with English textbooks. Whatever linguistic gap remained was often filled by the widely differing Chinese competency of the educated missionary women who served as instructors; otherwise, where instructors

12 Ryōsai kenbo was a major influence on what was more popularly known as "virtuous wives, good mothers" thinking in China, but there were several variants on this theme circulating in the popular press. It is important to note that in the Japanese version the emphasis on science was predominantly concerned with scientific child-rearing and scientific management of the household oriented towards national production. In China, the popularity of science within the "virtuous wives, good mothers" discourse tended towards improvement of the citizenry and of general standards of living.

13 Burton explains that in addition to a dearth of qualified instructors, some of the difficulty Chinese girls' schools encountered was linguistic. There were, for instance, several Japanese women who taught in China but had to do so through translators. 
were hired from overseas, attempts were sometimes made to bridge the gap through simple demonstration and experiments, which they also hoped would foster independent reasoning (Burton 1911, 136). ${ }^{14}$

From the 1890 s to the early 1900s, the availability of missionary instructors prepared to teach basic science courses in China's rapidly expanding network of girls' schools also benefitted from patterns in post-Civil War American women's education that made mathematics and sciences such as botany, geology, and astronomy morally reassuring alternatives to questionable subjects like literature (Rossiter 1982, 8; Tolley 2003, chap. 5). ${ }^{15}$ The impact of American women's education was felt even more acutely in the 1910s and 1920s, when teachers raised with Progressive era notions of motherhood began to staff Chinese schools. ${ }^{16}$ American maternalist politics were quite diverse, but they generally concerned themselves with the ways in which women were naturally better equipped to address problems associated with immigration, urbanization, and industrialization. This move to "mother" less fortunate groups outside of the home differed from the concerns of Chinese reformers, who wanted women to revitalize the nation and race from within the family unit, but one strain of maternalist thought struck a deep chord: home economics. Home economics, which emphasized the use of science to optimize the household and improve the well-being of children, seemed like a particularly effective way of producing "good wives" and "wise mothers" in a modern society (Elias 2008; Schneider 2011).

With the founding of the Republic of China in 1912, new legislation was passed to regulate normal schools at the provincial and national levels and to license primary school teachers (Li 2012, 424) (Figure 1). The instability of the new regime made this more of a dream than a reality, but since the shortage of qualified teachers was such an acute problem, the government was finally forced to make formal curricular provisions for women's normal schools, with home economics as an important component.

14 The methods and standards of all forms of girls' education in China were highly variable, often depending on the abilities of individual teachers, the class interests of the student body, and local gentry support. However, American Protestant missionary educators formed associations to discuss their experiences in China, consider new pedagogical ideas, and determine standards where possible. See, for instance, the records of the Educational Association of China and Appendix B, "Courses of Study: Schools for Females" in Gee 1905.

15 For an interesting intersection of American and Chinese women's interests in natural history, see the request from Luella Miner (then instructor in geology at Bridgman's Academy for Girls 北京貝滿女子學校) to US Congregational churches asking parishioners to collect specimens from around the country to send to China to replace the geological collection that she had lost during the Boxer Rebellion (Tenney 1903).

16 This flow of instructors from the US to China marks the convergence of the Student Volunteer Movement and the frustrations of university-educated women who could not find suitable employment in America. 


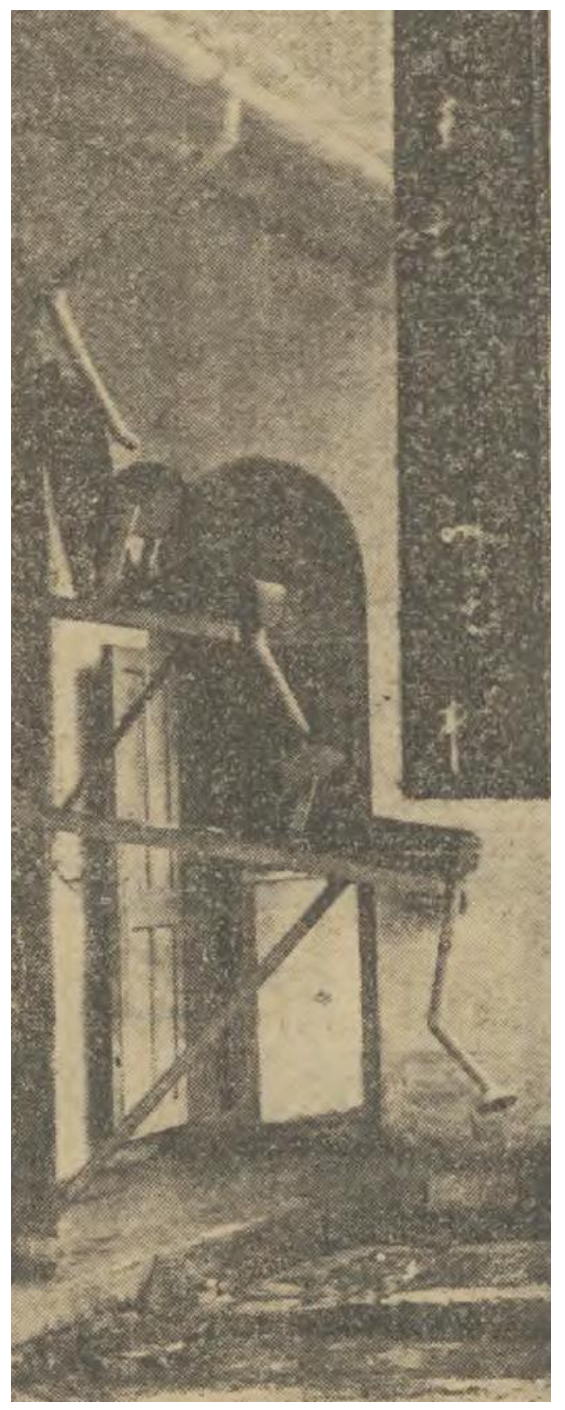

Figure 1: At the kindergarten run by Jiangsu No. 2 Women's Normal School, a simple machine of pipes and water wheels is built under the eaves of the school building to demonstrate hydraulic power when it rains ('Jiangsu Di'er Nüzi Shifan" 1924).
Despite the influence of American home economics, however, its impact in China was notably different. While the growth of home economics in the US offered many women with existing degrees in the sciences a way of finding relevant work in an otherwise unwelcoming academic job market, in China, home economics gave higher-level women's schools a reason to expand their basic science offerings and actually created the conditions for women to contemplate pursuing the sciences more formally. At the Beijing Women's Normal School, for instance, the goal was to train women to run their own households and teach home economics, but for students in the four-year program, far more instructional hours were devoted to mathematics, science, physics, and chemistry than to sewing, gardening, or handicrafts (Cong 2011, 93-94). Even for the vast majority of women in the normal school who did not seek further exposure to the sciences, the scientific bent of home economics shifted motherhood discourse in ways that led more and more women away from homemaking and into the professional world of teaching.

\subsection{Science in missionary colleges}

By the 1910s, several domestic and transnational factors came together to introduce science training for women at the collegiate level. The adaptation of home economics to the Chinese context, missionary interest in staying at the forefront of educational development in China, and the growing interest of American philanthropic organizations in raising technical standards created a hospitable environment for the establishment of China's first colleges for women. North China Union Women's College 華北協和女子大學 graduated its first class in 1909; Ginling College 金陵女子大學 followed suit in 1919 and Hwa Nan College 華南女子文理學院 in 1921. These three institutions were all missionary 
projects, but Beijing Women's Normal School also became Beijing Women's Higher Teachers' College in the fall of 1919,17 and in 1920, after allowing the first women to audit courses in 1919, women were also admitted to Peking University, China's premier institution of higher learning. Of the pioneering missionary college cohorts who majored in the sciences, two students became medical doctors and two returned from advanced study abroad to serve as presidents of their respective alma maters for several decades, suggesting the strong link between the educational ethos of these schools and scientific training. ${ }^{18}$

Of the early women's colleges, the most prominent was Ginling College, located in Nanjing. Ginling was founded as an interdenominational Christian college and led by Matilda Thurston, a Mount Holyoke graduate whose goal was to offer a broad liberal arts program equal in quality to those of the best women's colleges in America. ${ }^{19}$ Ginling aimed to teach women, but it eschewed the notion of gendered learning and resisted having a formal home economics department until 1940, even though the discourse of domestic science was a major driver of student interest. Instead, Ginling faculty encouraged students to explore both the arts and sciences until they felt comfortable choosing their own area of focus.

From the outset, the college offered astronomy, biology, chemistry, hygiene, mathematics, physics, and psychology at the college level, in addition to Latin, religion, sociology, music, history, English, and Chinese as part of the arts requirements (Figure 2). ${ }^{20}$ Ginling had an impressive and well-equipped science building as well as well-credentialed faculty from American institutions, and after the Guomindang nationalization of education in China, it established distinct science departments, of

17 Beijing Women's Higher Teachers' College opened with a new departmental structure, which included mathematics, physics, chemistry, mineralogy and biology, and household management, in addition to literature, history and geography, and foreign languages (Cong 2011, 93).

18 These two women, who earned degrees in biology and chemistry from the University of Michigan as Barbour Scholars, were Wu Yifang 吴贻芳, who was president of Ginling College from 1928-1951, and Wang Shijing 王世静 (Lucy C. Wang), who served as president of Hwa Nan College from 1930-1953. Though not a Chinese woman, Luella Miner, who founded North China Union Women's College, was also active in the sciences and wrote the first Chinese language textbook on geology. See Mai 1911.

19 From the outset, Ginling undergraduates received degrees granted through the Regents of the State of New York. See "The University of the State of New York Charter of Board of Founders, Ginling College," http://divinity-adhoc.library.yale.edu/UnitedBoard/Ginling_College/ Box\%20124/RG011-124-2589.pdf. Beginning with the class of 1923, Hwa Nan graduates also received degrees granted by the Regents of the State of New York, but the first two graduating classes did not receive the imprimatur of a foreign body (Wallace 1956, 24-26).

20 All courses other than Chinese were taught in English using standard textbooks, and in the brochure "Ginling College: Nanking, China, 1915-1919," it is noted that Mandarin as a spoken language was often less familiar to students, who came from all across China, than English, which they had all studied in secondary programs. See http://divinity-adhoc.library.yale.edu/ UnitedBoard/Ginling_College/Box\%20155/RG011-155-2967.pdf. 
which chemistry drew the most majors (Bays and Widmer 2009, 325). To appreciate the success of Ginling's science offerings, one might list some of the many prominent scientists and research doctors among its alumnae, including innovator in spectroscopy He Yizhen 何怡贞 (1937 University of Michigan PhD), chemist Wu Maoyi 吴禁仪 (1939 Radcliffe PhD), physical geographer and pioneer in oceanography Liu Enlan 刘 恩兰 (1940 Oxford PhD), and botanist Hu Xiuying 胡秀英 (1946 Radcliffe PhD), to name only a few. ${ }^{21}$ However, a more telling measure would be the $25 \%$ of all graduates

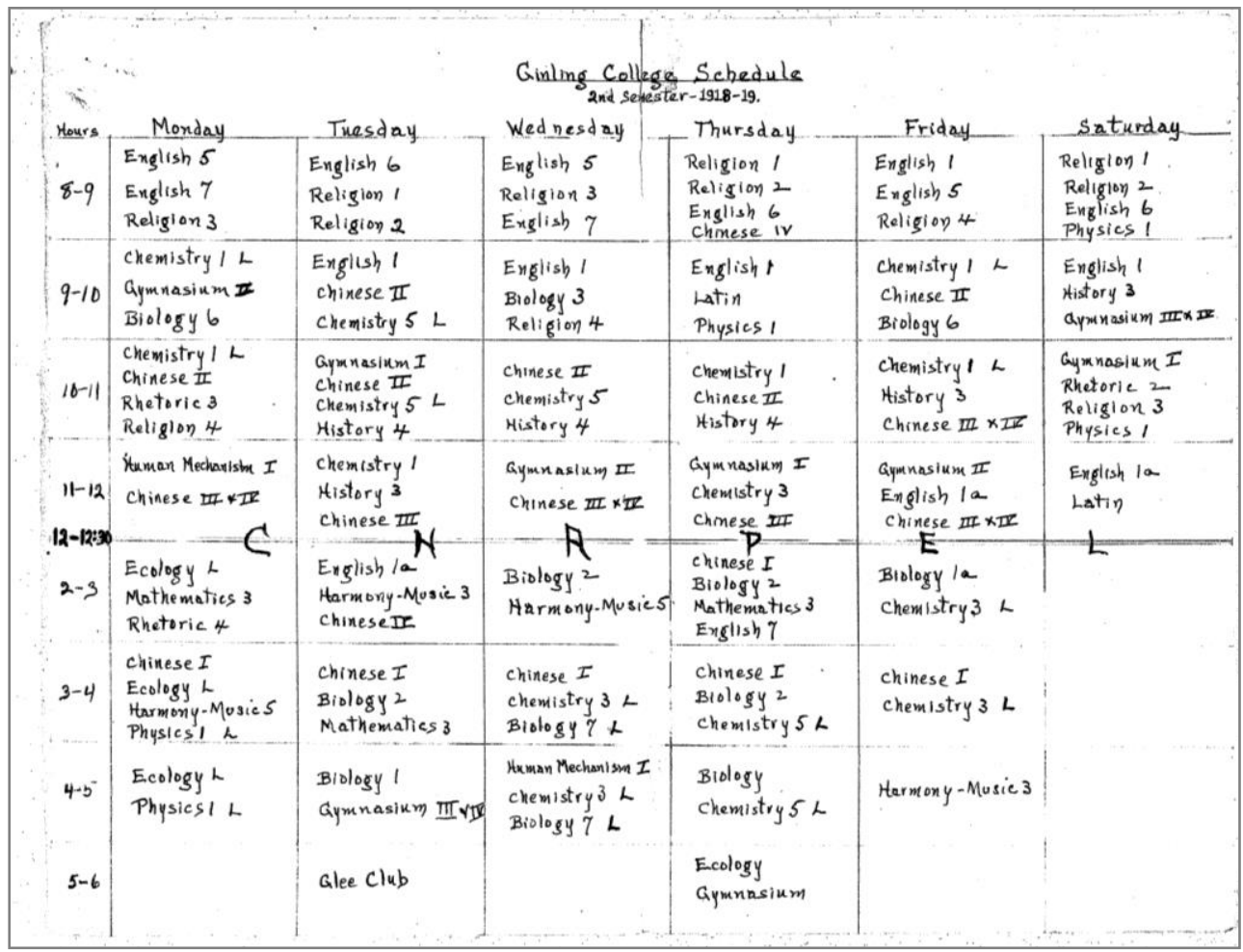

Figure 2: Ginling College, schedule of course offerings for 1918-1919 (Special Collections, Divinity School Library, Yale University, Archives of the United Board for Christian Higher Education in Asia (UBCHEA). RG 11 Series IV China College Files Box 156 2975).

21 These women graduated after the 1920s, and their success as research scientists marks a later development in which professional careers became more commonplace for women. I mention them to suggest the growing strength of Ginling's science departments, which became real alternatives to undergraduate study abroad by the late 1920s. Among Ginling graduates before the mid-1920s, many who majored in the sciences became teachers, missionaries, and administrators, but another mark of the strength of the Ginling program is that nine of these early graduates later completed advanced degrees in biology, chemistry, psychology, or medicine as Barbour Scholars at the University of Michigan. 
(1919-1950) who majored in either the sciences or, after 1927, a specialized scientific discipline (chemistry ranked as the third most popular major overall). ${ }^{22}$ As Yang Di 杨 笛 has recently pointed out, the proportion of science majors in Ginling's early years is even more startling, with three of its first five graduates earning a science degree and fourteen of twenty-three graduates doing so in $1921 .^{23}$

Ginling's exceptional ability to foster Chinese women's interest in the sciences at a time when rigorous scientific training was also difficult for Chinese men to acquire cannot be credited to any one factor. Matilda Thurston set the tone by insisting on China's need for modern science, which obviously resonated with the patriotic youth, but Ginling students-who often engaged in the sciences and Christianity with similar enthusiasm-were at once more practical and less narrowly focused than the ideologues of the May Fourth Movement. Ginling also benefited from its highbrow objectives, believing that it could offer an education equal to that of any modern institution of higher education anywhere and refusing to accept students who were insufficiently prepared. ${ }^{24}$ Together, these two founding orientations made a virtue of Ginling's single-sex mission. As alumna Mei Ruolan 梅若兰 recalled in an oral history interview, her class at Ginling once collaborated on a particularly tricky chemistry project with students from the University of Nanjing 金陵大學, which was co-educational. In the laboratory, female students from the University of Nanjing, who were used to the male students taking the lead in dangerous experiments, were hesitant to do the labwork, while Ginling students, who were accustomed to working independently, had no problem taking action and figuring out what to do (Jin 2007).

This confidence and hands-on attitude was cultivated by Ginling's dedicated science faculty, many of whom were American women PhDs or, later, Chinese graduates of Ginling who returned to teach after doing advanced work abroad. Ginling's faculty not only emphasized experiential learning in the laboratory or the field, they also made ingenious use of their surroundings to localize knowledge and

22 Dr. Ruth M. Chester (1916 Smith MA, 1934 Columbia PhD), taught chemistry at Ginling College from 1917 to 1939 and served as Dean of Studies through the occupation of Nanjing and into the 1940s. The college boasted several other accomplished faculty in chemistry, but Chester's influence was clearly a factor in the popularity of the field. Chemistry was also strong at Hwa Nan College, which might be attributable to the relevance of nutritional chemistry to home economics and the scientific interests of its first Chinese president, Wang Shijing.

23 These statistics closely follow Yang Di's excellent study of Ginling graduates and the college's unusual recipe for success in the sciences. See Yang 2016.

24 Because of the unevenness of secondary education, most prestigious universities in China offered a preparatory program at this time, and Ginling opted to take in a small incoming class rather than compromise its standards. "Ginling College: Nanking, China, 1915-1919," p. 6, http://divinity-adhoc.library.yale.edu/UnitedBoard/Ginling_College/Box\%20155/RG011-155-2 967.pdf. 
overcome the material deficiencies of the college's leaner years (especially later, during wartime). In good times, Dr. Cora Reeves (1917 University of Michigan PhD), who chaired Ginling's biology department for decades, had been known to joke about collecting molds and fungi from the stone floors of her damp laboratory when nothing else was available. ${ }^{25}$ Later, when the War of Resistance forced Ginling westward, faculty adjusted coursework to involve studies of local conditions and assigned projects that would materially affect neighboring farmers. ${ }^{26}$

Examples of engaged scientific inquiry abound in the many remembrances published about Ginling College, but perhaps the greatest object lesson that students received was simply that women could excel at the sciences if they wanted to. There were a few men who taught the sciences at Ginling, but it was the women, both American and Chinese, who stood out as role models. They demonstrated that scientific training could continue past the undergraduate level and that overseas study, though daunting, was always an option. They also offered a vision of professional life that did not need to involve marriage to be fulfilling. One former student recalled of her female science professors, "they earned their own salary and ... were not married.... People respected them." 27 Whether Chinese women scientists who attended Ginling married or not, they often recalled the sense of choice that they felt. ${ }^{28}$

At the same time that Ginling College was establishing itself as a women's institution, North China Union Women's College was struggling to negotiate and execute its amalgamation into a larger, co-educational Yenching University 燕京大學， which would put Yenching at the forefront of co-education in China. North China Union's president, Luella Miner 麦美德, felt pressure to offer a complete range of electives for her students and did not think this was feasible without merging with the men's Christian universities around Beijing (Wakeman 2007, 149). A unified curriculum was put in place to accomplish this by 1921, but Miner was adamant that the Women's College, which retained control of its own funds and land until 1927, also retain a distinct character in its new form, the College of Arts and Sciences for Women of Peking University 北京大學女子文理學院 (Boynton 1921). After Miner's resignation in 1922, successive deans of the Women's College grappled with both the problem of maintaining an institutional voice for women and the rising tide of anti-foreign feeling

25 “Ginling College: Nanking, China, 1915-1919," p. 9, http://divinity-adhoc.library.yale.edu/ UnitedBoard/Ginling_College/Box\%20155/RG011-155-2967.pdf.

26 Chang Tuh-wei, "Need for Education of Women in China Today," in http://divinity-adhoc. library.yale.edu/UnitedBoard/Ginling_College/Box\%20159/RG011-159-3013.pdf.

27 Deng Yuchi, quoted in Sasaki 2016, 105.

28 According to Jane Hunter, the choice that many Ginling women made to stay single in pursuit of education and service was less shaped by the model of American missionary women than it was by a sense of their own unique ability to contribute to urgent national needs (Hunter 1984, 248-250). 
in the Nanjing Decade (1927-1937), but instructional integration seemed quite successful and female students adapted quickly to sharing classrooms and committees (Wakeman 2007, 150).

The political climate in Beijing (later Beiping) made the most popular courses for women at Yenching University economics, political science, sociology, and history (Wakeman 2007, 154), but a thriving sub-culture of female students developed in the physics department under Paul Andersen, William Band, and a growing roster of returned Chinese PhDs (Hu 2014). The example of physics in the late 1920s and 1930s suggests some of the growing pains of co-educational science training for women in this transitional period. Some, like future Tsinghua professor Wang Mingzhen 王明贞 (BS 1930; MS 1932), actually transferred to Yenching from Ginling College after having a negative experience with the grading there. ${ }^{29}$ Later, women tended to enroll in the undergraduate program directly, as was the case for plasma physicist Wang Chengshu 王承书 (BS 1934; MS 1936). Not all co-educational departments were as welcoming as at Yenching, however, and when nuclear physicist He Zehui tested into Tsinghua University's physics program in 1932, Department Chair Ye Qisun 叶企孙 famously tried to get He to transfer because he did not think that a woman could handle the rigors of physics (she later graduated with the highest grades in her class and went on to become a CAS academician) (China Central Television 2015).

For female students interested in the sciences in Republican China, there was no obvious path and no one-size-fits-all solution to the problems of being a trailblazer. Some future scientists, such as physicist Gu Jinghui 顾静徽, needed considerable exploration to find their calling. Gu finished middle school, experimented with teacher training, and then enrolled in Utopia School 大同學院 (Utopia University 大同大學 after 1922), which was a radical experiment in Chinese higher education based in Shanghai and spearheaded by former Tsinghua College professors. There, Gu developed an interest in science, and in 1923 she won a government scholarship to study physics at Cornell University before earning her $\mathrm{PhD}$ in physics from the University of Michigan in 1931. Unfortunately, many women found themselves locked into work or family obligations before such chances appeared. Before the mid-1920s normal schools with science departments did not seem to teach with enough emphasis on research to tempt many students away from the secure job prospects available in education. Women's colleges continued to be a strong option, but domestic science

29 Based the pronouns used in her short autobiography, it seems as if a male instructor gave Wang a bad grade in physics based on his impressions rather than a careful review of her final examination (Wang 2006, 176). Given others' glowing descriptions of Ginling, this suggests that perhaps men were less enthusiastic about teaching at a women's college and paid less attention to their duties. A similar phenomenon affected men at American women's colleges, who saw their posts as temporary stepping stones to better appointments or as a last resort (Rossiter 1982, 174-180). 
degrees generally led to positions in education or administration rather than research. In contrast, China's leading co-educational universities were centers of research, and by the 1930s women were studying scientific disciplines in an ever-widening range of public and private universities. But as opportunities widened, many encountered discrimination that they had not experienced before or found themselves uncomfortably noticeable in male-dominated classrooms. Others who felt that the options in China were too limiting simply rolled the dice and went abroad to try their hand at college in unfamiliar surroundings.

\section{Study abroad}

For historians of science, the story of late Qing and early Republican Chinese students going abroad feels well worn and familiar. Driven by a desire to strengthen their homeland, waves of students rushed outward to learn Western methods and norms at their source. Returned students established the Science Society of China 中国科学社, remade Chinese higher education and research institutions, wooed foreign experts and funders, and engaged both political and cultural leaders to produce a new China, often at breakneck speed and yet never quite fast enough. This cycle of migration and return produced a well-connected and cosmopolitan scientific elite who were passionately committed to the betterment of China, though also alienated at times from broader society by their single-minded efforts to create change.

In recent years, scholars have added depth and nuance to this story, working through the complexities of transnational lives, global geopolitics, and local realities to uncover meaningful variations on the theme (see Wang and Guo 2019). However, little attention has been paid to female students who went abroad to study science and often returned with their own potent dreams of intellectual service. Whether this is because it is assumed that women scientists had little impact or that women's experiences simply mirrored those in male-centered accounts, it is eye-opening to consider that Wang Jichen 王季茞 (Chi Che Wang), the first Chinese woman to study sciences in the United States, arrived as a government-sponsored student in 1907, the same year that the Qing court first sanctioned primary education for women and two years before the first male Boxer Indemnity students were sent to America. Unlike the men who went abroad, her career trajectory had not been derailed by the abrogation of the civil service examination system in 1905; indeed, it is not clear what, if any, career prospects she could have expected at all. The presence of Chinese women going abroad for scientific training at such an early point forces us to think about the radicalness of overseas study in a new way. Why did women want to take such a risk for such an unclear payoff? What obstacles did women have to overcome to take such an opportunity? And how was it possible for these women to thrive in such unfamiliar circumstances? 


\subsection{Family background}

One of the biggest determinants in the lives of Chinese women who took up the sciences in the early twentieth century was family background. It is telling that in the case of Kang Aide, the Chinese doctor of Western medicine whom Liang Qichao famously celebrated as a model of China's new woman (Liang 1897), she was adopted as an infant and raised by the American missionary Gertrude Howe. ${ }^{30}$ This kept Kang from being socialized within a Chinese family and steeped her in an alternate (and quite idiosyncratic) set of norms and expectations that made her a difficult example for other Chinese women to follow. ${ }^{31}$

For the Chinese women in the early twentieth century who first pursued advanced training in the modern sciences, however, family was an inescapable part of their outlook and choices, and their paths reflected real shifts in the calculus of possibility for educated women. Two general profiles emerge among the women who earned degrees in the sciences. For one group, personal adversity and the vagaries of domestic politics unsettled more traditional family dynamics, and for the other, strong, supportive families transmitted an outward-looking ethos of female education and achievement.

Personal adversity could come in many forms and often led to difficult choices that rendered the issues of “independent personhood" (独立人格) that were being debated in the periodical press unavoidable necessities rather than voluntary aspirations. In the case of Wu Yifang 吴贻芳, who was born in 1893 to a minor official in Hubei, her father did not approve of women's education, and she and her elder sister were only able to attend a girls' school by threatening to harm themselves. When $\mathrm{Wu}$ Yifang was sixteen, her father was implicated in a case of fiscal mismanagement and killed himself, leaving her mother without any means of supporting four children and an elderly grandmother.

$30 \mathrm{Hu}$ Ying notes that not only was Kang Aide adopted and therefore removed from the context of her Chinese natal family, her personal history was also carefully curated and contested throughout her life, by herself, by Liang, and by missionary figures (Hu 2001). Kang was not the first Chinese woman to earn an MD in the United States. She was preceded by Jin Yunmei, who graduated from the Woman's Medical College of New York in 1885 and was the first Chinese MD of either gender, and she was joined in her studies at the University of Michigan by her adopted sister, Shi Meiyu 石美玉 (Mary Stone), who graduated with her in 1896. Though Jin charted a very different course than Kang and Shi, all three of these women were adopted at a young age by missionaries, from whom they learned English and by whom they were encouraged to serve both their native country and God through medical missionary service. Jin actually came to the United States at age 5 and then lived with her adopted parents in Japan for several years before returning to the US to study medicine. See Li 2018 for a discussion of Jin and other early Chinese women doctors as a distinct wave in the history of women's study abroad.

31 Howe not only trained her adopted children in English at a time when many missionaries were trying to teach scripture in Chinese, she also believed that all of her children should receive a higher education in America. When Kang traveled to the US in 1882, she went with not only her adopted sister Shi Meiyu but also three adopted brothers, all headed for college (Hu 2001, 211). 
Within a month, Wu Yifang's elder brother and sister committed suicide and her mother died of despair. In the midst of this trauma, Wu Yifang had to care for her younger sister and grandmother, but her uncle-in-law, Chen Shutong 陈叔通, who was a strong advocate of women's education, encouraged her to entrust them to him and go back to school in Hangzhou (Zhu 1993, 49). There, Wu Yifang converted to Christianity to help cope with her family trauma, developed an interest in science, and finished her secondary education at age twenty-one. She did not see any way of pursuing further study and opted to teach English to help out with family finances until she was invited to join the first class of the newly established Ginling College, where the average age of qualified entrants was twenty-three (Sasaki 2016, 105). At Ginling, she focused on biology, but given the lack of options for a woman interested in science, she decided to return to her family and teach English once again. While teaching, Wu Yifang did such an impressive job as translator for Mary Woolley, then president of Mount Holyoke, that she was recommended for a Barbour Scholarship to the University of Michigan, where she earned her PhD from the Biology Department in 1928, at the age of thirty-five (He 2017, 21). Though Wu Yifang did not continue with active scientific research while serving as president of Ginling College from 1928-1951, she strengthened her alma mater's commitment to the sciences and helped train several generations of Chinese women scientists.

Born in 1911, Lu Shijia's 陆士嘉 family turmoil was more directly related to politics but similarly disruptive on a personal level, and her experience demonstrates the ongoing struggles that women had in resisting expectations of family roles. Her grandfather, Lu Zhongqi 陸鐘琦, was a high-ranking official who once tutored the last emperor, Puyi 溥仪, and was resolutely loyal to the dynasty. Her father, Lu Guangxi 陸光熙, was a jinshi degree holder who had entered the Hanlin academy but also studied at the Imperial Japanese Army Academy, and who was rumored to have secretly joined the Revolutionary Alliance. When the Xinhai Revolution (1911) broke out in Shanxi, Lu Zhongqi had just been appointed provincial governor 巡抚 and refused to surrender to the revolutionary forces of the New Army. It is unclear whether Lu Guangxi rushed to his father's side to protect him or to convince him to accept the reality of the revolution (Sun 2016), but both men were killed and only Lu Shijia's mother and her three young daughters escaped. The remaining family members depended on Lu's maternal uncle, a doctor in Beijing, to make ends meet. Though Lu Shijia was sent to primary and secondary schools, her uncle balked at the cost of college and preferred that she marry, but she decided to put herself through college by teaching on the side and he could not force her to get engaged (Cai 1994, 42). Beiping Normal University, co-educational since 1921, had no tuition and ample opportunities to teach, and in 1929, at the age of eighteen, Lu Shijia entered not only as the only woman in the Physics Department but as one of the younger students in the class. She 
supported herself by teaching physics at a girls' secondary school, and by 1937 she had saved enough money to escape the impending war with Japan and go with her fiancé, Zhang Wei 张维, to Germany, where the cost of study abroad was low. In Germany she convinced "father of aerodynamics" Ludwig Prandtl to accept her as a graduate student, and she graduated from Göttingen University in 1942 before winning funding from the Humboldt Stiftung en route to later achievements as a leader in aerodynamics in the People's Republic of China (Cai 1994, 43).

For women such as $\mathrm{Wu}$ and $\mathrm{Lu}$, family misfortunes not only tested their mettle, they also loosened the strictures of growing up in traditional households. Amidst so much family turmoil, $\mathrm{Wu}$ Yifang unbound her feet at girls' school without any family resistance, and Lu Shijia never had her feet bound at all. Wu remained both single and single-mindedly devoted to education, ${ }^{32}$ while Lu was able to choose her own husband and did not marry until she was thirty. This would have been unheard of in a family of Lu Zhongqi's stature. Moreover, what might have remained a pleasant interest in science turned into a way of establishing independence, both financially and socially. Both women found ways to educate themselves at an advanced level, and in so doing, they not only relieved others of the burden of supporting them but also opened up space for their personal ambitions and their hopes of serving the nation.

The experiences of the second type of Chinese female scientist, whose strong families supported female education and had the social wherewithal to soften the risk of flouting gender conventions, might seem less dramatic, but they had even more active choices to make. Daughters of supportive families still had to grapple with the difficulties of separation as they attended distant modern schools and later traveled overseas. Financial considerations were an issue whether or not families were open to female achievement, and such considerations determined whether a woman had to try to go abroad on a competitive and restrictive government scholarship or whether she could become a self-funded student with more latitude to choose a course of study. Marriage was still a potential obstacle, especially for women whose lives became transnational in the pursuit of science. Assuming they could escape the expectation to marry early, would they be able to find a suitable partner later if they wanted? Even supportive families had to weigh the risk of their prized daughters traveling alone to study science when job prospects were completely unpredictable and social ties were difficult to maintain at a distance. Moreover, choices such as whether or not to bind a daughter's feet were usually made by age six, and given that only women with natural feet could receive Boxer Indemnity support, futures could be determined by decisions

32 According to Yang Di's research, both $\mathrm{Wu}$ and her closest friend, $\mathrm{Xu}$ Yizhen 徐亦蓁, served as translators for Mary Woolley. Xu gave up the chance to go to the University of Michigan in favor of $\mathrm{Wu}$ because she was already engaged to be married and she knew that $\mathrm{Wu}$ had no such ties to hold her back (Yang 2012, 93). 
made long before any interest in the sciences had developed.

Nevertheless, for many future women scientists, a progressive family made all the difference. In plant geneticist Shen Liying's 沈网英 family, the world outside of China had already become familiar conceptual territory by the time she left home to study at Wellesley in 1921. Her father, Shen Chengyi 沈承懌 (later Shen Hong 沈纮), had moved to Paris in 1904, where he became a doctor of law and then (according to some accounts) died in 1916 while completing a PhD in science, likely related to agriculture (Lü 2013, 55). One of his dying requests was that one of his children study agriculture, and though Shen Liying was the one to switch from literature to biology (MS Cornell 1929) and breed a "miracle" strain of wheat, her two sisters and brother were also highly accomplished doctors and engineers (Liu 2013).

Similarly, world-renowned nuclear physicist $\mathrm{Wu}$ Jianxiong 吴健雄 (Wu Chien-Shiung) was also heavily influenced by her father, Wu Zhongyi 吴仲裔. Wu Zhongyi was the son of a xiucai 秀才 and began his education at a traditional Chinese school before entering the Nanyang Public School (南洋公學, a precursor of Jiaotong University). He joined Sun Yat-sen's (孙逸仙，孙中山) Revolutionary Alliance and later fought against Yuan Shikai's 袁世凱 seizure of power in 1915 (Chiang 2014, 4). Wu Zhongyi gave his daughter a fundamental belief that men and women were equal in their potential and encouraged her to dream big. Hoping to inspire her to learn science as a way to serve the nation, he even challenged her to construct a working radio from a jumble of parts. After his daughter's birth in 1912, Wu Zhongyi established Mingde Vocational School 明德女子職業補習學校, which Wu Jianxiong attended before she received her grandmother's blessing to board at Suzhou Second Women's Normal School (Zhu 2001, chap. 1, 54-55). Years later, Wu still credited her career as an experimental physicist at UC Berkeley, on the Manhattan Project, and most famously at Columbia University to her father's influence and encouragement, which pushed her towards science rather than simply allowing it.

Despite these positive trajectories, strong and supportive families were not always enough to overcome the dislocations of advanced study abroad. If we return to Wang Jichen, who arrived in the United States in 1907, we see another side of the story. Wang graduated from Wellesley College in 1914 and became the first Chinese woman to earn a doctoral degree in the sciences when she earned a PhD in Food Chemistry from the University of Chicago in 1918. ${ }^{33}$ After her PhD, Wang continued her research at several Chicago-area universities, hospitals, and industrial concerns, and was elected a member of the American Association for the Advancement of Science in 1921. Wang, who became an American citizen in 1947, continued to conduct and publish research

33 This was also the first PhD granted by the Home Economics Department in this specialty, and she was the first woman PhD at Chicago (University of Chicago 1922). This helps us see her accomplishment as something notable in the American context as well as the Chinese. 
until her retirement in 1961, but she never returned to China (Kang and Li 2012, 173). The reasons for this refusal, which contrasted with her sisters' timely return from study abroad, seem to have been that she was married (or betrothed) to Yuan Liangsu 袁梁肅, the son of one of her father's prominent friends, and that if she returned to China, Wang would have had to face a relationship she was unwilling to accept (Kang and Li 2012, 168). In Wang's case, her early achievements, including study in Japan before 1906, had been strongly supported by her mother, Wang-Xie Changda 王謝長達, a well-known promoter of women's education, but the same family networks that made her pioneering education possible also made it imperative that Wang Jichen honor the social obligations of her otherwise open-minded parents. In a patriotic family with deep intellectual roots, overseas study of a prestigious and modern subject was Wang's only escape from an unwanted marriage, and unlike many Republican-era men who faced a similar choice, she preferred to embrace a new life as an unattached scientist in America. ${ }^{34}$

\subsection{Strategies of mobility and community}

In addition to enriching our understanding of the role played by overseas study in the development of modern China, stories of Chinese women scientists' global quest for advanced training can also add an important dimension to the way we frame the progress of women's participation in the sciences in general. Studies rooted in European and American contexts presume the existence of a scientific establishment from which women were excluded and by which early female participation was either exploited or effaced. In contrast, Chinese women were pursuing advanced studies in science at roughly the same time as their male counterparts, and while gender differences certainly shaped their experiences, the scientific establishment in China was still very much under construction in the first decades of the twentieth century. It is therefore important to understand that even though the Republican era "woman

problem" (妇女问题) was built on an assertion of transnational sisterhood, women in science did not always face the same struggles.

In the Russian case, for instance, there were several women by the late nineteenth

34 Several prominent May Fourth era men, such as Hu Shi 胡适 and Lu Xun 鲁迅, struggled to balance their modern, cosmopolitan lives with arranged marriages, but it was more common for women who felt pulled by individual desires or vocational demands to remain single rather than to accept family obligations or search for a like-minded love match. A student at Ginling College even suggested that men were jealous of women's ability to throw marriage aside (Yang 2012, 79), and it is intriguing to consider whether male expectations of active social engagement in the national project actually tied them to the convention of marriage (traditional or otherwise). Alternately, it might be illuminating to revisit overseas students to analyze whether men remained abroad for personal reasons and have simply been written out of narratives focused on nation-building and modernity. 
century who were actively involved in scientific societies, producing work under the guidance (and often the names) of fathers or husbands, or auditing courses at leading universities as irregular students. In contrast to the Chinese situation at the turn of the twentieth century, public lectures in science were in vogue, and since well-bred women were expected to be multi-lingual, they often translated scientific works for their male relatives (Valkova 2008, 139). It was therefore plausible for Russian women to gain a solid background in the sciences within the household before considering what to do with their hobby. For them, study abroad was an expedient that they used to obtain recognition for an existing reality. Women like Nadezhda Suslova, who earned her medical doctorate from Zurich University in 1867, had already audited a significant number of courses in St. Petersburg and only needed the chance to complete a dissertation to certify her achievement (Koblitz 1988, 215-216). Others, such as the celebrated Sofia Kovalevskaia, who became the first woman to earn a doctorate in mathematics in 1874 and even went so far as to contract a fake marriage in order to go to Göttingen University, simply longed for the chance to study their chosen fields as men could (Valkova 2008, 146-147). ${ }^{35}$

The problem for the Russian government was that university degrees were the entry point into the civil service, and as more and more women displayed interest and proficiency in the sciences, it became apparent that they would demand state diplomas (Valkova 2008, 141-142). To avoid this, the government banned women from attending university courses in 1863, and this meant not only that study abroad became the only way for Russian women to obtain scientific training, but that study abroad became an explicit challenge to the Czarist state. This politicized character not only swelled the ranks of women who sought degrees in Switzerland and Germany, it also had a double impact on the rate of attrition. When, in 1874, the state decreed that women with foreign degrees would be denied access to licensing exams to practice science and medicine, it not only scared some women into returning home without a degree, it also provoked others to simply abandon science for outright revolutionary activities. Given such circumstances, the fact that only $20 \%-30 \%$ of the Russian women who went abroad to pursue science between 1865-1890 completed advanced degrees must be interpreted with great care, and it is perhaps more significant that there was a wave of 500-700 such women in this period at all (Koblitz 1988, 220-222).

In America, where universities were not centrally regulated by the state in the same way, women interested in the sciences were less radical and employed what Margaret Rossiter has described as a multi-decade strategy of "infiltration" whereby "individual women sought to test the repressive system on as many fronts . . . as possible, probing for weak points and using what friends they had to help them evade the rules

35 It is interesting to note that in this context marriage was a potential path to freedom of mobility rather than a limiting factor that automatically tied women to the home. 
informally" (Rossiter 1982, 31). Though each case was different, a considerable degree of coordination emerged with the goal of parlaying informal arrangements into official changes in policy that would result in the conferral of actual degrees. Frustrated that the only American universities in the 1870s and 1880s that would grant them doctorates were considered lesser lights, American women in the sciences also turned their attention to study abroad, but with the aim of initiating change at home. They began with Swiss universities, which already admitted women graduate students, but the goal was to conquer the prestigious German institutions, which served as academic benchmarks for the rest of the world until the early 1900s. This strategy not only made use of women of exceptional scientific ability and resilience as a crucial vanguard, it also capitalized on foreign and local dynamics. For instance, German professors and universities who were concerned about admitting local women were considerably more amenable to foreign women who had no intention of teaching in the German system. Similarly, the opening of German universities put pressure on American institutions such as Harvard, Johns Hopkins, and Princeton to match the shifting European standard (Rossiter 1982, 37-43). As a welcome side effect, the successes that foreign women had in earning advanced degrees in the sciences at German institutions also set a precedent that finally allowed talented local women such as chemist Clara Immerwahr to enjoy similar privileges after the turn of the century. ${ }^{36}$

A somewhat better comparison to the Chinese case might be that of Japan, where the scope of women's exposure to science and access to education was similarly constrained by familial roles. Whereas American women primarily saw scientific training as a matter of personal interest and women's rights, and Russian women before 1917 felt the need to choose between their commitments to sociopolitical activism and their interest in science, Chinese and Japanese women understood science itself to be revolutionary, whether or not they used that term explicitly. Both societies prized science as the key to modernity, wealth, and power, all of which was expected to fundamentally transform local conditions and challenge global hierarchies. However, under the Meiji government, the Japanese process of self-conscious modernization took off several decades earlier and was shaped by imperial ambitions that did less damage to patriarchal institutions than in China. This meant that by the early twentieth century, there already existed a scientific establishment that was extremely gendered, and the

36 Koblitz points out that even in Switzerland, where university policies were more liberal than elsewhere in Europe, few local Swiss women attended graduate school, especially in the sciences. In part this was due to social norms that made foreign graduate students (especially Russian) appear unseemly and unsettling, but it was also due to the fact that Swiss students, unlike foreigners, were required to have a gymnasium diploma. What is most important for us is the recognition that progress in women's scientific education is contextual and uneven rather than linear, and that women could often leverage outsider status to their advantage (Koblitz 1988, 214-215). 
few women who rejected the incredibly powerful force of the ryōsai kenbo ideology were at a considerable disadvantage. Women were absolutely barred from graduate work at imperial universities, ${ }^{37}$ and when accomplished cytologist Yasui Kono 保井科 诺 finally went abroad for advanced study in the United States in 1914, the government required her to add "domestic science" to her research in order to justify their approval. 38

In China, on the other hand, the relative novelty of the modern sciences and its attendant institutions meant that women were not fighting against an entrenched scientific establishment in the same ways as American, European, and Japanese women were. ${ }^{39}$ Chinese women, despite the newness of their right to an education at all, were actually at the forefront of a broad campaign to bring scientific knowledge home to China, and both the late Qing and the Republican states viewed them with optimism rather than suspicion. Of course, in foreign universities in the early twentieth century, Chinese women also benefited from the many battles that late-nineteenth-century American and European women had already waged to win the right to higher education. Chinese women did not go abroad to circumvent discrimination in their own universities, they (like their male compatriots) went abroad in response to a general scarcity of domestic options. Modern departments of science in China only began to be established in the late 1910s and only became co-educational in the 1920s. Similarly, though the best Chinese universities started to grant master's degrees in the 1920s, students could not earn PhDs domestically, and training abroad conferred both prestige and exposure to the cutting edge of scientific research. For Chinese women, the scarcity of technical personnel and China's urgent need for such skills offered the hope that advanced degrees would allow them to harness the prestige of foreign science and

37 Though the imperial university system was established in 1877, women were barred from enrollment at any level. In 1913 the president of Tohoku Imperial University admitted three women as undergraduates, all of whom studied mathematics or chemistry. This decision was censured and no further women were admitted by Tohoku until 1923. Kyushu Imperial University admitted women in 1925 and Hokkaido Imperial University and Osaka Imperial University followed suit in 1935. Acceptance was slow, sporadic, and hotly contested. For more, see Kodate and Kodate 2016, chap. 1.

38 Of the 3209 students that the Japanese government sponsored to go abroad between 1875-1940, only thirty-nine were women, most of whom studied English or physical education (Otsubo 2005, 469).

39 In some ways, the talented women who studied natural phenomena in the Chinese literati tradition had more in common with women in Russia, Germany, America, and Japan. Their achievements were often not recognized within intellectual society more broadly and, despite their high social standing, their learning was not always considered appropriate for women. Of course, the comparison is imperfect because "scientific" research was never in the mainstream of traditional Chinese intellectual attainments and the amateur ideal produced a very different economy of recognition and certification. However, the idea of women working against established traditions and expectations is still better suited to the literati frame than to the early Republican era. For more on Qing dynasty women "scientists," see Shen 2011. 
leap-frog over educational and professional inequalities at home.

\section{Conclusion}

"One had to have immense bravery and energy to go against society, family, and friends and set out alone for far-off places in search of science" (Koblitz 1988, 218-219). Though radical feminist P. N. Arian said this about Russian women scientists, it was just as true for Chinese women. Consideration of women's pursuit of science in the late Qing and early Republican period suggests that the stories we have become accustomed to, whether centered on men and nationalism or Western women and equality, are not the only stories that need to be told about the early development of modern Chinese science. The importance of science for China's future was never, no matter how patriotic one was, a straightforward and inevitable reason to overturn one's life. Wu Yifang recalled that early in her studies at Hangchow Union Girls' School 杭州 弘道女子學堂, she heard a lecture that “made aspirations of enriching the nation and strengthening the people spring up in my young heart, and these have been engraved in my heart for decades" (使我幼小的心灵萌发了富国强民的志向, 而且数十年来一直铭 记在心) (Zhu 1993, 8). Nevertheless, when she had the opportunity to follow her intellectual ambitions and go to the University of Michigan to study biology on a prestigious scholarship, she hesitated because of family obligations and would have sacrificed the opportunity if not for her uncle's encouragement.

Historians must take more seriously the personal considerations of choosing science and leaving behind familiar social settings to seek advanced training, both at home and abroad. It has always been clear that China's early pioneers of science were doing something groundbreaking, but looking through the lens of women allows us to revisit just how unusual the choice to study science was, and though it is perhaps more obvious for women, we must turn a similar eye to men. What did it mean to board at a modern school, take classes with speakers of very different dialects, study through textbooks in more than one foreign language, and then leave for distant lands where everything from food to friendships had to be re-imagined? How did science look when it was counterposed not just to traditional natural knowledge or Confucian humanism but to marriage and physical comfort?

Then again, the Chinese case also forces us to question whether our assumptions about power relations and gender dynamics need to be reconfigured for highly mobile groups navigating both domestic upheaval and transnational reorientations. Chinese women in the late Qing and early Republican period faced overwhelming obstacles in the pursuit of science, beginning with limited opportunities for elementary scientific education and encompassing countless social challenges in a society where women were still imagined to be unsuited for roles outside of family and home. But precisely 
because of their struggles to obtain basic education at home, Chinese women were often particularly equipped to flourish during their study abroad. For instance, Chinese women were less likely than their male counterparts to have begun their schooling in a traditional setting, and women who were qualified to study abroad were often forced to attend a Christian school where (by the 1900s) English was the primary language of instruction or to go to a competitive Chinese school that followed the best missionary institutions in emphasizing English study. This added difficulty posed an initial barrier for many, but it paid dividends later for those that went abroad. While women were not necessarily better than men at English, their linguistic confidence made it easy for them to excel at public speaking and hold publicity or editorial positions in organizations such as the Chinese Students Alliance of America.

Whether or not students were actually Christian, the dominance of missionary schools in scientific education for girls also meant that Chinese women studying in America were often very comfortable with campus social activities that would have been quite foreign to the uninitiated Chinese student. Students at Ginling College, for instance, participated in activities of the Young Women's Christian Association (YWCA), had a Glee Club and Oration Club, played sports like tennis, baseball, and volleyball, and organized volunteer work. ${ }^{40}$ For those students who studied in the United States, there was very little difficulty in making the transition to either women's colleges or co-educational graduate settings. ${ }^{41}$ In contrast to Chinese men, who were often stereotyped as physically weak or indisposed to physical activity despite considerable interest in intramural sports, the emphasis of both gentry and missionary schools on women's physical education was a social asset for Chinese women in Western educational settings. For those who actually were Christian, religious organizations also offered Chinese women a voice beyond the confines of the Chinese student community, and Chinese women were well represented at national conferences. ${ }^{42}$ Those students who had attended women's colleges in China also found a rich network of supporters at American sister institutions, and many were recommended for admission and scholarships on the basis of alumnae connections. What seemed like gender segregation or marginalization within the Chinese context took on new meanings overseas.

40 See, for example, "Ginling Vignettes," http://divinity-adhoc.library.yale.edu/UnitedBoard/ Ginling_College/Box\%20156/RG011-156-2975.pdf.

41 Here, I differ from Li 2018, which frames Chinese female students' preference for women's colleges as a sign of cultural conflict that signaled a less progressive outlook. Given the state of women's higher education worldwide in the early twentieth century, women's colleges were hardly regressive, and in European settings, where women's colleges were not an option, Chinese women were also very successful at integrating into predominantly male educational settings.

42 See, for example, news of Chinese women at the Student Volunteer Movement conference held in Kansas City, MO in 1914. "Y.W.C.A." Messenger, January 1914, 31. 
The foreign setting of study abroad not only exposed Chinese women to local communities, it also forced Chinese men and women to interact in new ways that were surprisingly egalitarian. Chinese women were active in the overseas student communities wherever they studied. They formed associations throughout Europe and the United States, ${ }^{43}$ and some, such as the ones that developed in Japan and France, had a particularly significant political impact. In scale and ambition, though, the Chinese Students' Alliance in America was most notable and influential, and through the pages of its journals and meeting minutes, it is clear that men and women worked side by side in their common interest. This habit of cooperative and equal engagement made a formative impression on generations of influential returned students, perhaps nowhere more obvious than in the establishment of the Science Society of China in 1914. From these interactions in situ, it is clear that the experience of scientific study abroad must be understood as much in terms of life course and happenstance as in terms of degrees and professional credentials, as much for Chinese men as for Chinese women. Tempting as it is to read the rise of the sciences in China exclusively in terms of national salvation or modernization, science in the early twentieth century was never an obvious choice for either Chinese men or women, and we cannot appreciate its full significance without re-examining how it became a viable part of Chinese intellectual identities, both gendered and national.

\section{References}

Bailey, Paul. 2007. Gender and Education in China. New York: Routledge.

Bays, Daniel, and Ellen Widmer. 2009. China's Christian Colleges: Cross-Cultural Connections, 1900-1950. Palo Alto: Stanford University Press.

Boynton, Grace M. 1921. “A Co-Educational Celebration.” Women's Work 36 (1): 12-14.

Burton, Margaret. 1911. The Education of Women in China. New York: Fleming H. Revell.

Cai, Delin 蔡德麟. 1994.“Tansuo de xiaozu, pulu de shizi: Nü liutilixuejia lixue jiaoyujia Lu Shijia” 探索的小卒 铺路的石子-一女流体力学家、力学教育家陆士嘉 [Foot-soldier of exploration, paving stone: Female dynamicist and mechanics educator Lu Shijia]. Xuehui 学会 [Learned Society] 3:42-44.

China Central Television. 2015. “Dajia: Zhuming hewulixuejia He Zehui” 大家: 著名核物理学家 何泽慧 [Masters: The famous nuclear physicist He Zehui]. Aired October 8, 2015. Accessed July 3, 2019. http://tv.cntv.cn/video/C10309/47934ef7086b47b7a3aa6407f9e3818e.

Chen, Pingyuan 陈平原. 2008. “Male Gaze/Female Students: Late Qing Education for Women as Portrayed in Beijing Pictorials, 1902-08," translated by Anne S. Chao. In Different Worlds of Discourse: Transformations of Gender and Genre in Late Qing and Early Republican China, edited by Nanxiu Qian, 315-347. Leiden: Brill.

Chen, Yuanhui 陈元晖, Chen Xuexun 陈学恂, and Tian Zhengping 田正平. 2007. Zhongguo jindai

43 See, for example, Club Chinesischer Studenten 1927. 
jiaoyushi ziliao huibian: Liuxue jiaoyu 中国近代教育史资料汇编一一留学教育 [Compendium of sources of modern Chinese educational history: Study abroad]. Shanghai: Shanghai Education Press.

Chiang, Tsai-Chien. 2014. Madame Wu Chien-Shiung: The First Lady of Physics Research, translated by Wang Tang-Fong, ch. 1, esp. p. 4. Singapore: World Scientific Publishing Company.

Club Chinesischer Studenten [Chinese Students Club]. 1927. Jahrbuch des Club Chinesischer Studenten E. V. (25 Jahre) [25th anniversary yearbook of Chinese student clubs in Germany]. Glückstadt and Hamburg: J. J. Augustin.

Cong, Xiaoping. 2011. Teachers' Schools and the Making of the Modern Chinese Nation-State, 1897-1937. Vancouver: University of British Columbia Press.

Dong, Lijuan 董丽娟. 2018. “Qingdai nükexuejia qunti tezheng tongji yanjiu” 清代女科学家群体 特征统计研究 [A statistical research on the group characteristics of female scientists in the Qing dynasty]. Ziran bianzhengfa tongxun 自然辩证法通讯 [Journal of Dialectics of Nature] 40 (3): 68-73.

Educational Association of China. 1909. Records of the 1st-7th Triennial Meeting, Volume 1. Shanghai: American Presbyterian Mission Press.

Edwards, Nancy Jocelyn. 1997. “The Science of Domesticity: Women, Education and National Identity in Third Republic France, 1880-1914." PhD diss., University of California Berkeley.

Elias, Megan J. 2008. Stir It Up: Home Economics in American Culture. Philadelphia: University of Pennsylvania Press.

Gao, Pingshu. 1996. "Cai Yuanpei's Contributions to China's Science." In Chinese Studies in the History and Philosophy of Science and Technology, edited by Fan Dainian, Tai-nien Fan, and Robert S. Cohen, 395-418. Dordrecht: Kluwer Academic Publishers.

Gee, Nathaniel Gist. 1905. The Educational Directory for China: An Account of the Various Schools and Colleges Connected with Protestant Missions, and Also Government and Private Schools Under Foreign Instruction. Suzhou: Educational Association of China.

Goodman, Bryna. 2005. “The Vocational Woman and the Elusiveness of 'Personhood' in Early Republican China." In Gender in Motion: Divisions of Labor and Cultural Change in Late Imperial and Modern China, edited by Bryna Goodman and Wendy Larson, 265-286. London: Rowman \& Littlefield Inc.

He, Sitong 赫思童. 2017. “Jiaoyujia Wu Yifang geti chengzhangshi yanjiu” 教育家吴贻芳个体成 长史研究 [Study of the personal development of educator Wu Yifang]. Master's thesis, Tianjin Normal University.

$\mathrm{Hu}$, Danian 胡大年. 2014. “Bridging East and West through Physics: William Band at Yenching University." In Science and Technology in Modern China, 1880s-1940s, edited by Jing Tsu and Benjamin Elman, 245-268. Leiden: Brill.

Hu, Ying. 2001. “Naming the First New Woman." Nan Nü: Men, Women and Gender in China 3 (2): 196-231.

Hunter, Jane. 1984. The Gospel of Gentility: American Women Missionaries in Turn-of-the-Century China. New Haven, CT: Yale University Press.

“Jiangsu Di'er Nüzi Shifan Fushu Xiaoxue kexue huanjing” 江蘇第二女子師範附屬小學科學環境 [The scientific environment at the kindergarten run by Jiangsu No. 2 Women's Normal School]. 1924. Shenbao: Jiaoyu yu rensheng zhoukan 申報: 教育與人生週刊 [Shenbao: Education and life 
weekly] (46): 602.

Jin, Yihong 金一虹. 2007. Nüxing xushi yu jiyi 女性叙事与记忆 [Women's narrative and memory]. Beijing: Jiuzhou Press.

Kang, Jing 康静, and Li Yanping 李艳平. 2012. “Zhongguo diyiwei nü huaxue boshi-Wang Jichai" 中国第一位女化学博士一一王季茞 [The First Female Chinese PhD in Chemistry-Wang Chi Che]. Zhongguo kejishi zazhi 中国科技史杂志 [The Chinese Journal for the History of Science and Technology] 33 (2): 167-175.

Koblitz, Ann Hibner. 1988. "Science, Women, and the Russian Intelligentsia: The Generation of the 1860s." Isis 79 (2): 208-226.

Kodate, Naonori, and Kodate Kashiko. 2016. Japanese Women in Science and Engineering: History and Policy Change. New York: Routledge.

Latimer, John. 1958. What's Happened to Our High Schools? Washington, DC: Public Affairs Press.

Lee, Lily Xiao Hong, and A. D. Stefanowska, eds. 2015. Biographical Dictionary of Chinese Women, Volume III: Antiquity through Sui, 1600 B.C.E.-618 C.E. New York: Routledge.

Lee, Lily Xiao Hong, and Sue Wiles, eds. 2015. Biographical Dictionary of Chinese Women, Volume II: Tang through Ming, 618-1644. New York: Routledge.

Lewis, Ida. 1919. The Education of Girls in China. New York: Teacher's College, Columbia University.

Li, Jian 李建. 2018. “Qingmo Minchu nüxing liuxue jiqi wenhua chongtu jingyu tanjiu (1869-1925)” 清末民初女性留学及其文化冲突境遇探究 (1869-1925) [Analysis of women's study abroad and the predicament of cultural conflict in late Qing dynasty and early Republic of China (1869-1925)]. Chongqing wenli xueyuan xuebao (shehui kexue ban) 重庆文理学院学报 (社 会科学版) [Journal of Chongqing University of Arts and Sciences (Social Sciences Edition)] 37 (4): 57-64.

Li, Jun. 2012. "The Chinese Model of Teacher Education: Retrospects and Prospects over a Century." Frontiers of Education in China 7 (3): 417-442.

Liang, Qichao 梁啟超. 1897. “Ji Jiangxi Kang nüshi” 記江西康女士 [Biographic record of Ms. Kang from Jiangxi]. Shiwu bao 時務報 [The Chinese Progress] 21:2b-3a.

Liang, Qichao. [1897] 2013. “On Women's Education," translated by Robert Cole and Wei Peng. In The Birth of Chinese, edited by Lydia Liu, Rebecca Karl, and Dorothy Ko, 189-203. New York: Columbia University Press.

Lin, Lezhi 林樂知 [Young J. Allen]. 1903. “Quandi wudazhou nüsu tongkao xu”全地五大洲女俗 通考序 [Survey of female customs on the five continents of the world]. Wanguo gongbao 萬國公 報 [The Globe Magazine] 176: 12-15.

Liu, Xiaoyi. 2009. "The Rise of Women's Modern Schooling in Late Qing China (1840-1911)." Jiaoyu xuebao 教育學報 [Education Journal] 37 (1-2): 89-117.

Liu, Yuanzhao 柳袁照. 2013. “Shen Liying, Shen Zonghan yu Shen Junshan” 沈网英、沈宗翰与沈 君山 [Shen Liying, Shen Zonghan, and Shen Junshan]. Zhongguo jiaoyu bao 中国教育报 [Chinese Education Daily] January 9, 2013, 7.

Lü, Chao 吕超. 2013. “Qingmo Riyu fanyi Shen Hong yijie huodong chutan” 清末日语翻译沈纮 译介活动初探 [Research on the translation activities of Japanese translator Shen Hong in the late Qing Dynasty]. Zhejiang Waiguoyu Xueyuan xuebao 浙江外国语学院学报 [Journal of Zhejiang International Studies University] (1): 54-58, esp. 55. 
Mai, Meide 麦美德 [Sarah Luella Miner]. 1911. Dizhi xue 地质学 [Textbook of geology]. Peking: North China Union Women's College.

Otsubo, Sumiko. 2005. "Women Scientists and Gender Ideology." In A Companion to the Anthropology of Japan, edited by Jennifer Robertson, 467-482. Malden, MA: Blackwell.

Qian, Nanxiu. 2003. "Revitalizing the Xianyuan (Worthy Ladies) Tradition: Women in the 1898 Reforms." Modern China 29 (4): 399-454.

Rossiter, Margaret. 1982. Women Scientists in America: Struggles and Strategies to 1940. Baltimore: Johns Hopkins University Press.

Sasaki, Motoe. 2016. Redemption and Revolution: American and Chinese New Women in the Early Twentieth Century. Ithaca, NY: Cornell University Press.

Schneider, Helen M. 2011. Keeping the Nation's House: Domestic Management and the Making of Modern China. Vancouver: University of British Columbia Press.

Shemo, Connie. 2011. The Chinese Medical Ministries of Kang Cheng and Shi Meiyu, 1872-1937: On a Cross-Cultural Frontier of Gender, Race, and Nation. Lanham, Md.: Rowman \& Littlefield.

Shemo, Connie. 2018. "Christianity, Modernity, and Women Physicians in China: The Southern Methodist Commitment to Medical Education for Chinese Women in Suzhou, 1891-1918." In Christianity and the Modern Woman in East Asia, edited by Garrett L. Washington, 14-37. Leiden: Brill.

Shen, Grace. 2007. "Murky Waters: Thoughts on Desire, Utility, and the 'Sea of Modern Science.'” Isis 98 (3): 584-596.

Shen, Yuwu 沈雨梧. 2011. Qingdai nü kexuejia 清代女科学家 [Qing dynasty women scientists]. Zhejiang: Zhejiang Education Press.

Shurtleff, William and Aoyagi Akiko. 2016. “Biography of Yamei Kin M. D. (1864-1934), (Also Known as Jin Yunmei), the First Chinese Woman to Take a Medical Degree in the United States (1864-2016): Extensively Annotated Bio-Bibliography, 2nd ed." Soy Info Center. Last modified March 25, 2016, accessed July 1, 2019. http://www.soyinfocenter.com/pdf/192/Kin.pdf.

Sun, Hongqi 孙红旗. 2016. “Xinhai Shanxi Guangfu shiqi renwu Lu Guangxi shishikao” 辛亥山 西光复时期人物陆光熙史事考 [Investigation of the historical facts of Guangfu era personage Lu Guangxi during the Xinhai Revolution in Shanxi]. Baicheng shifan xueyuan xuebao 白城师范 学院学报 [Journal of Baicheng Normal University] 30 (7): 79-82.

Tenney, H. Melville. 1903. “A Unique Opportunity for Service” The Pacific 53 (43): 10.

Tolley, Kim. 2003. The Science Education of American Girls: A Historical Perspective. New York: RoutledgeFalmer.

University of Chicago. 1922. Register of Doctors of Philosophy of the University of Chicago, June 1893-December 1921. Chicago: University of Chicago Press.

Valkova, Olga. 2008. "The Conquest of Science: Women and Science in Russia, 1860-1940." Osiris Intelligentsia Science: The Russian Century, 1860-1960 23 (1): 136-165.

Wakeman, Carolyn. 2007. "Beyond Gentility: The Mission of Women Educators at Yenching." The Journal of American-East Asian Relations 14:143-171.

Wallace, Lydia Ethel. 1956. Hwa Nan College: The Woman's College of South China. New York: United Board for Christian Colleges in China.

Wang, Mingzhen 王明贞. 2006. “Zhuanshun jiushi zai” 转瞬九十载 [Ninety years in a flash]. Wuli 物理 [Physics] 35 (3): 174-182. 
Wang, Xiaohui 王晓慧. 2015. Jindai Zhongguo nüzi jiaoyu lunzheng shi yanjiu (1895-1949) 近代中国 女子教育论争史研究 (1895-1949) [History of controversies in modern Chinese women's education (1895-1949)]. Beijing: China Social Sciences Press.

Wang, Yan. 2015. "Moving to Shanghai: Urban Women of Means in the Late Qing." In Gender and Chinese History: Transformative Encounters, edited by Beverly Jo Bossler, 161-181. Seattle: University of Washington Press.

Wang, Zuoyue 王作跃, and Guo Jinhai 郭金海. 2019. “Transnational Mathematics and Movements: Shiing-shen Chern, Hua Luogeng, and the Princeton Institute for Advanced Study from World War II to the Cold War." Chinese Annals of History of Science and Technology 3 (2): 118-165.

Wu, Minxiang 吴民祥. 2010. “Zhongguo jiaoyu zaoqi xiandaihua de dute yuezhang-Qingmo nüzi xuetang jiaoyu zhi kaocha” 中国教育早期现代化的独特乐章一一清末女子学堂教育之考察 [A unique movement in the modernization of Chinese education: Investigation of girls' school education in the late Qing]. Huadong Shifan Daxue xuebao (Jiaoyu kexue ban) 华东师范大学学报 (教育科学版) [Journal of East China Normal University (Educational Sciences)] 28 (1): 60-68.

Wu, Xiao'ou 吴小鸥, and Li Xiang 李想. 2014. “Fuquan nüxing: Wanqing Minguo nüzi jiaokeshu de qimeng suqiu” 赋权女性: 晚清民国女子教科书的启蒙诉求 [Empowerment of women: Enlightenment aspirations in women's textbooks of the late Qing dynasty and the Republican China]. Huadong Shifan Daxue xuebao 32 (1): 103-110.

Xiong, Xianjun 熊贤君. 2006. Zhongguo nüzi jiaoyu shi 中国女子教育史 [History of Chinese women's education]. Taiyuan: Shanxi Education Press.

Yang, Di 杨笛. 2012. “Zai hunyin yu shiye zhijian” 在婚姻与事业之间 [Between marriage and career]. PhD diss., Nanjing University.

Yang, Di. 2016. "Chongpo kexue de xingbie fanli-Jinling Nüzi Daxue de jiaoyu shijian jiqi qishi" 冲破科学的性别焚篱——金陵女子大学的教育实践及其启示 [Breaking through the barriers of science and gender: The enlightenment of educational practice of Ginling College]. Funü yanjiu luncong 妇女研究论从 [Collection of Women's Studies] 1:39-52.

Ye, Weili. 2002. Seeking Modernity in China's Name: Chinese Students in the United States, 1900-1927. Palo Alto: Stanford University Press.

Zhu, Xuebo 朱学波. 1993. Wu Yifang (Jiangsu wenshi ziliao di 60 ji) 吴贻芳（江苏文史资料第 60 辑) [Wu Yifang (Jiangsu literary and historical materials, volume 60]). Nanjing: Jiangsu Literary and Historical Materials Compilation Bureau.

Zhu, Yuelin. 2001. "Chien-Shiung Wu: An Intellectual Biography." PhD diss., Harvard University. 